\title{
Heat processing (HTST) of umbu (Spondias tuberosa Arruda Câmara) pulp
}

\author{
Tratamento térmico (HTST) de polpa de umbu (Spondias tuberosa Arruda Câmara)
}

\author{
Emanuelle Araújo de OLIVEIRA ${ }^{1}$, Soraia Vilela BORGES'2*, Ângela Aparecida Lemos FURTADO ${ }^{3}$, \\ Regina Célia Della MODESTA ${ }^{3}$, Ronoel de Oliveira GODOY ${ }^{3}$
}

\begin{abstract}
Umbu pulp is an important product in the economy of the northeastern region of Brazil, and its preservation can be ensured by heat treatment. A complete factorial design with 2 factors (time and temperature) and 3 central points was used to verify the effect of the HTST process on the physicochemical, chemical, physical, microbiological, and sensory qualities of umbu pulps. The results showed that the heat treatments applied resulted in products without significant alterations on the physicochemical, chemical, and microbiological characteristics. With respect to color, the parameters $\mathrm{L}$ and $\mathrm{a}^{\star}$ were altered by increases in temperature indicating by darkening of color. The sensory evaluation indicated that a treatment of $88^{\circ} \mathrm{C}$ for 10 seconds was the best processing condition due to the greater similarity of the resulting product to the reference sample (blanched pulp).

Keywords: food quality; chemical composition; food processing; fruit; sensory analysis; physical properties.
\end{abstract}

\section{Resumo}

A polpa de umbu é um importante produto na economia da região semiárida do Brasil e sua conservação pode ser estendida por tratamento térmico. Um planejamento fatorial completo com 2 fatores (tempo e temperatura) e 3 pontos centrais foi utilizado para verificar o efeito do processo HTST sobre a qualidade físico-química, química, física, microbiológica e sensorial de polpas de umbu. Os resultados mostraram que o tratamento térmico aplicado resultou em produtos sem significantes alterações nas características físico-químicas, químicas e microbiológicas. Com respeito à cor, os parâmetros $\mathrm{L} e \mathrm{a}^{\star}$ foram alterados pelo aumento da temperatura, indicando um escurecimento na cor. A avaliação sensorial indicou que o tratamento $88^{\circ} \mathrm{C}$ por 10 segundos foi a melhor condição de processamento, devido à maior similaridade do produto resultante com a amostra referência (polpa branqueada).

Palavras-chave: qualidade do alimento; composição química; processamento de alimentos; fruta; análise sensorial; propriedades físicas.

\section{Introduction}

Umbu (Spondias tuberosa Arruda Câmara) is a fruit of great economic importance to the semi-arid northeastern region of Brazil since it is used in the manufacture of pulps, preserves, and jams, amongst other products (POLICARPO et al., 2003; JORGE et al., 2004).

Among the main methods used to preserve fruit pulps, heat treatment is one of the most commonly used aiming mainly at reducing the microbial load. However, the heating process can affect the quality of the product due to non-enzymatic browning and the destruction of pigments (LOZANO; IBARS, 1997).

The time and temperature used depend on the heat resistance of the microorganisms to be destroyed and on the heat sensitivity of the food; therefore, various studies can be found in the literature using different time-temperature binomials. The heat treatments applied to acidic fruit juices such as umbu, whose $\mathrm{pH}$ is around 2.5 to 2.8 (NARAIN et al., 1992), generally consist of blanching and pasteurization. Temperatures of $77-98^{\circ} \mathrm{C}$ and times varying from 30 seconds to 15 minutes have been used for different pulps, purees, and fruit juices such as graviola puree (UMME et al., 1997), pear puree
(IBARZ; PAGÁN; GARZA, 1999), apple pulp (VALDERRAMA; MARANGONI; CLEMENTE, 2001), and passion fruit juice (SANDI et al., 2003). With respect to umbu pulp, Jorge et al. (2004) the use of blanching $\left(100{ }^{\circ} \mathrm{C} / 3\right.$ minutes $)$ and slow pasteurization $\left(63{ }^{\circ} \mathrm{C} / 30\right.$ minutes $)$ showed that this treatment was sufficient to guarantee a shelf life of 120 days for pulps at $30{ }^{\circ} \mathrm{C}$.

The HTST (High Temperature-Short Time), heat processing of foods, is known to result in a greater retention of quality factors such as flavor, color, texture, and nutrients, and it has mostly been applied to fruit juices (KRAPFENBAUER et al., 2006; RIVAS et al., 2006) and dairy products. However, this process has not yet been used for umbu pulps and could be an interesting alternative to slow pasteurization.

Therefore, the objective of the present study was to investigate the best time/temperature combination in order to establish the best conditions for the heat treatment of umbu pulps by the HTST process aiming at minimizing the loss or destruction of some quality aspects. 


\section{Material and methods}

\subsection{Raw material}

The fruits in the mature green stage used in this study were harvested in Campina Grande, Pernambuco, Brazil and were transported by air in frozen state to Embrapa Agroindustria de Alimentos, RJ, Brazil.

\subsection{Pulp production}

Upon reception, the fruits were thawed, weighed, and blanched at $100{ }^{\circ} \mathrm{C} / 3$ minutes in a jacketed vat to facilitate pulping and inactivate the enzymes (JORGE et al., 2004). They were then submitted to the pulping operation in an electric horizontal pulper (model: Bonina 0.25 Df A8, Itametal, Brazil), equipped with a $2.5 \mathrm{~mm}$ sieve and polyethylene scraper, and operated at a maximum rate of $10 \mathrm{~kg} / \mathrm{batch}$. The pulp was collected in clean stainless steel recipients and stored in containers (5 L) previously sanitized with a $20 \mathrm{mg} \cdot \mathrm{kg}^{-1}$ chlorine solution. The fibrous material, seeds, and skin were separated for subsequent weighing, and the pulp refined in the same pulper using a $0.6 \mathrm{~mm}$ sieve. Part of the resulting pulp was used in the physicochemical and microbiological analysis, and the rest was stored at $-18^{\circ} \mathrm{C}$ in low density polyethylene bags for subsequent heat processing.

\subsection{Chemical and physicochemical analysis}

The following analysis were carried out according to the AOAC (ASSOCIATION..., 2000) norms: pH using a pHmeter - method no 973.41; total soluble solids - method no 932.14; total titratable acidity expressed in terms of citric acid - method no 942.15; ether extract, obtained by acid hydrolysis - method $\mathrm{n}^{\circ}$ 922.06; ash content obtained by calcination of the organic material after carbonization - method no 923.0; moisture content determined by drying at $70{ }^{\circ} \mathrm{C}$ in a vacuum oven to constant weight - method $\mathrm{n}^{\circ} 934.06$; and phosphorus, calcium and iron contents - method $\mathrm{n}^{\circ}$ 9.2.39. The protein contents were determined using the traditional Kjeldahl method, modified according to AACC (AMERICAN..., 1995) no 46-13. The total carotenoids were quantified at $450 \mathrm{~nm}$ in a Specord UV-Visible spectrophotometer model 205 (Analytik Jena, Germany) according to the technique proposed by Amaya (2001).

\subsection{Microbiological analysis}

The following microbiological analyses were applied to the samples: coliforms (most probable number - MPN); yeasts and molds (expressed as CFU.g ${ }^{-1}$ ); the standard plate count (expressed as CFU.g ${ }^{-1}$ ); and the determination of Salmonella (result expressed as the presence or absence in $25 \mathrm{~g}$ ). The methodologies used were those indicated by Speack (1976).

\subsection{Heat treatment}

Table 1 shows the experimental design used for the study of the heat treatment based on preliminary tests according to Rodrigues and Iemma (2005). The results were analyzed statistically using the software Statistica 5.0 (Stat Soft, Tulsa,
USA) based on the evaluation of the effects on the variables and an analysis of variance of the linear model regarding the experimental design.

The heat treatment was applied using an Armfield type FT 74 PT-90 scraped surface heat exchanger (Armfield, UK) suitable for viscous products. The equipment also had a cold water cooling unit that ensured an outlet temperature of about $20^{\circ} \mathrm{C}$. The heat exchange occurred in three units, and the first was the pre-heating unit, followed by the unit that heated to a fixed temperature, and finally the cooling unit. In order to fit the process, some parameters were fixed such as pressure, length of the retention tube, diameter of the tubing, and the volume of this section. The flow rate was modified according to the process time.

After the heat treatment, the product was transferred to the ultra-clean filling unit, in which it was filled into $300 \mathrm{~mL}$ plastic bottles previously sanitized by immersion in a $20 \mathrm{mg} \cdot \mathrm{kg}^{-1}$ chlorine solution for 20 minutes followed by rinsing in running water treated with $3 \mathrm{mg} \cdot \mathrm{kg}^{-1}$ chlorine. The bottles were reserved for subsequent analysis and/or stored frozen for later analysis.

\subsection{Color analysis}

The instrumental color analysis was carried out by reflectance in a S \& M Color Computer, model SM - 4- CH (Suga, Japan) using the Hunter system with a $30 \mathrm{~mm}$ diameter aperture. The color parameters measured in relation to the white plate were: $\mathrm{L}=90.23 ; \mathrm{a}=-2.34$; and $\mathrm{b}=1.39$, where: $\mathrm{L}=$ luminosity $(0=$ black and $100=$ white $)$, a $(-80$ to zero $=$ green; zero to $+100=$ red $), \mathrm{b}(-100$ to zero $=$ blue; zero to $+70=$ yellow $)$. The samples were placed on $5 \mathrm{~cm}$ diameter Petri dishes ( $2 \mathrm{~cm}$ height) and four repetitions were carried out.

\subsection{Sensory evaluation}

The sensory evaluations of the umbu pulp were carried out by nine trained judges and were divided into the following steps: determination of the attributes, training of the judges, and sensory tests. Due to its considerable acidity, the umbu pulp had to be diluted to a soluble solids content of about $3{ }^{\circ} \mathrm{Brix}$ in order to determine the attributes. For training, the nine judges received diluted samples from each process separately, in order to evaluate them in relation to the reference (diluted blanched pulp). Additional training was carried out for further five days in order to evaluate the intensity of each attribute as compared

Table 1. Experimental design for the heat treatment.

\begin{tabular}{cccccc}
\hline Trials & \multicolumn{2}{c}{ Temperature } & & \multicolumn{2}{c}{ Time } \\
\cline { 2 - 3 } \cline { 5 - 6 } & $\begin{array}{c}\text { Coded } \\
\text { variable }\left(\mathrm{X}_{1}\right)\end{array}$ & $\begin{array}{c}\text { Temp } \\
\left({ }^{\circ} \mathrm{C}\right)\end{array}$ & & $\begin{array}{c}\text { Coded } \\
\text { variable }\left(\mathrm{X}_{2}\right)\end{array}$ & $\begin{array}{c}\text { Time } \\
(\text { seconds })\end{array}$ \\
\hline 1 & -1 & 88 & & -1 & 10 \\
2 & -1 & 88 & +1 & 30 \\
3 & 0 & 92 & 0 & 20 \\
4 & 0 & 92 & 0 & 20 \\
5 & 0 & 92 & 0 & 20 \\
6 & 1 & 96 & -1 & 10 \\
7 & 1 & 96 & 1 & 30 \\
\hline
\end{tabular}


to the reference. After this period, all samples were presented together as well as the reference sample, which was coded. The final evaluation was carried out by means of a multiple comparison test using the diluted blanched umbu pulp as the reference sample. Each analysis was carried out with three repetitions in sensory booths. The samples were evaluated under white light and the sample presentation was balanced. No sugar was added to the umbu pulps and they were served in $50 \mathrm{~mL}$ white plastic cups coded with three-digit numbers. To cleanse the palate between samples, the judges were served room temperature mineral water and cream crackers. The results were analyzed statistically by the analysis of variance and Dunnett's test at probability level of $95 \%$. A value of 5 was attributed to samples showing no difference from the reference, and values of $4,3,2$, and 1 to samples showing slight, moderate, considerable, and extreme differences from the reference for a determined attribute, and values of 6 (slight), 7 (moderate), 8 (considerable), and 9 (extreme) for samples showing greater number of the attributes (STONE; SIDEL, 2004).

\section{Results and discussion}

\subsection{Chemical and physicochemical characterization of the umbu pulp}

Table 2 shows the results obtained for the chemical and physicochemical analyses of the blanched pulp. The values found for the $\mathrm{pH}$ and titratable acidity of the blanched pulp were close to those found by Policarpo et al. (2003) of 2.68 and $1.5 \mathrm{~g} .100 \mathrm{~g}^{-1}$, respectively, for umbu pulp blanched at $100^{\circ} \mathrm{C}$ for 5 minutes. The moisture content was close to the values found by Bispo (1989) and Bueno et al. (2002) of 89.9 and 89.4 g.100 g-1 The soluble solids content found $\left(8.96^{\circ} \mathrm{Brix}\right)$ was higher than that found by Policarpo et al. (2003) for blanched umbu pulp (8.0 ${ }^{\circ}$ Brix); and lower than that found by Bueno et al. (2002) for commercial umbu pulp (10.1 $\left.{ }^{\circ} \mathrm{Brix}\right)$. The values for lipids and ash were close to those found by Bispo (1989) of 0.35 and 0.3 g. $100 \mathrm{~g} \mathrm{~g}^{-1}$, respectively. The calcium $\left(18.55 \mathrm{mg} .100 \mathrm{~g}^{-1}\right)$ and iron $\left(0.22 \mathrm{mg} .100 \mathrm{~g}^{-1}\right)$ contents were lower than those found by Bispo (1989) of 26.33 and $1.66 \mathrm{mg} .100 \mathrm{~g}^{-1}$, respectively. Narain et al. (1991) reported calcium contents of $15.1 \mathrm{mg} .100 \mathrm{~g} \mathrm{~g}^{-1}$ for umbu fruits, slightly lower than the values found in the present study. The iron and phosphorous contents reported by the same author (1.4 and $23.9 \mathrm{mg} .100 \mathrm{~g}^{-1}$, respectively) were higher than the values found in the present study. With respect to total carotenoids, the value found $\left(0.76 \mathrm{mg} .100 \mathrm{~g}^{-1}\right)$ was lower than that found by Xavier (1999) for industrialized umbu pulp $\left(12.03 \mathrm{mg} .100 \mathrm{~g}^{-1}\right)$. This accentuated difference was due to a variety of factors such as, for example, the state of maturity of the fruits and the processing and storage conditions (time and temperature) and also the methodologies used.

The values found for the parameters $\mathrm{L}^{*}, \mathrm{a}^{\star}$, and $\mathrm{b}^{\star}$ for the blanched pulp were similar to those reported by Policarpo et al. (2003) for blanched green umbu pulp $\left(\mathrm{L}^{*}=52.16 ; \mathrm{a}^{*}=1.93\right.$; $\left.\mathrm{b}^{\star}=22.50\right)$.

The estimate of the effects of time and temperature on the physicochemical properties (Table 3 ) shows that the treatments had no significant effect on these properties. As compared to the blanched pulp, a slight increase in acidity $(1.39 \%)$ can be seen for the most extreme time and temperature conditions, and also for the soluble solids content, which reached a maximum of $9.06^{\circ} \mathrm{Brix}$ for the process realized under these conditions ( $96^{\circ} \mathrm{C} / 30$ seconds). Similar results were found by Sousa et al. (2006) in the pasteurization of acaí pulps using temperature/ time combinations of $90^{\circ} \mathrm{C} / 10$ minutes and $100{ }^{\circ} \mathrm{C} / 1$ minutes.

In their study on green umbu pulp preserved by combined methods, Jorge et al. (2004) found a slight reduction in $\mathrm{pH}$ and acidity after pasteurization at $65{ }^{\circ} \mathrm{C} / 30$ minutes, which they considered to be due to a possible volatilization of organic acids. In their study on a comparison of heat processing methods for apple juice (HTST pasteurization and high voltage electric fields), Aguilar-Rosas et al. (2007) found no significant changes in the physicochemical properties as compared to the untreated juice.

According to the estimate of the effects (Table 4), there was no significant difference between the treatments for the chemical components analyzed. As compared to the blanched pulp (Table 2), it can be seen that the moisture content increased slightly during the processes. On the other hand, the protein content and ether extract showed slight decreases and the content of carotenoids varied slightly but not significantly reaching a maximum value of $0.79 \mathrm{mg} .100 \mathrm{~g}^{-1}$ under the processing conditions of $96^{\circ} \mathrm{C} / 10$ seconds. Other studies on the blanching or pasteurization of various products have shown

Table 2. Chemical and physicochemical characteristics of the blanched umbu pulp.

\begin{tabular}{|c|c|}
\hline Characteristics & Blanched umbu pulp \\
\hline $\mathrm{pH}$ & $2.95 \pm 0.01$ \\
\hline Total soluble solids ( $\left.{ }^{\circ} \mathrm{Brix}\right)$ & $8.96 \pm 0.02$ \\
\hline Total titratable acidity $\left(\mathrm{g} .100 \mathrm{~g}^{-1}\right)$ & $1.36 \pm 0.05$ \\
\hline Moisture content (g.100 g ${ }^{-1}$ ) & $89.04 \pm 0.35$ \\
\hline Protein content $\left(\mathrm{g} .100 \mathrm{~g}^{-1}\right)$ & $1.19 \pm 0.55$ \\
\hline Ether extract (g.100 g $\left.{ }^{-1}\right)$ & $0.41 \pm 0.03$ \\
\hline Ash content $\left(\mathrm{g} .100 \mathrm{~g}^{-1}\right)$ & $0.36 \pm 0.05$ \\
\hline Calcium content (mg.100 g $\left.\mathrm{g}^{-1}\right)$ & $18.55 \pm 0.20$ \\
\hline Iron content (mg.100 g $\left.\mathrm{g}^{-1}\right)$ & $0.22 \pm 0.10$ \\
\hline Phosphorous content (mg.100 g-1) & $14.42 \pm 0.22$ \\
\hline Total carotenoids (mg.100 g $\mathrm{g}^{-1}$ ) & $0.76 \pm 0.40$ \\
\hline$L^{*}$ & $40.75 \pm 0.25$ \\
\hline$a^{*}$ & $1.32 \pm 0.03$ \\
\hline$b^{*}$ & $22.58 \pm 0.02$ \\
\hline
\end{tabular}

Table 3. Estimate of the effects on the physicochemical properties.

\begin{tabular}{crrrrcc}
\hline $\begin{array}{c}\text { Factors/ } \\
\text { property }\end{array}$ & \multicolumn{2}{c}{$\mathrm{pH}$} & \multicolumn{2}{c}{$\begin{array}{c}\text { Soluble solids } \\
\left({ }^{\circ} \text { Brix }\right)\end{array}$} & \multicolumn{2}{c}{$\begin{array}{c}\text { Total titratable acidity } \\
\left(\mathrm{g} .100 \mathrm{~g}^{-1} \text { Citric acid) }\right.\end{array}$} \\
\cline { 2 - 7 } & \multicolumn{1}{c}{ Value } & $\mathrm{p}$ & Value & $\mathrm{p}$ & Value & $\mathrm{p}$ \\
\hline Mean & 2.94 & 0.00 & 8.98 & 0.00 & 1.36 & 0.00 \\
$\mathrm{X}_{1}$ & 0.00 & 1.00 & 0.05 & 0.48 & 0.02 & 0.32 \\
$\mathrm{X}_{2}$ & -0.00 & 0.42 & 0.05 & 0.48 & -0.02 & 0.32 \\
$\mathrm{X}_{1} \times \mathrm{X}_{2}$ & 0.00 & 1.00 & 0.05 & 0.48 & 0.00 & 0.71 \\
\hline
\end{tabular}

$\mathrm{X}_{1}$ : temperature; $\mathrm{X}_{2}$ : time. p: probability at $95 \%$ significance level. ${ }^{*}$ significant at $\mathrm{p}<0.05$. 
Table 4. Estimates for the effects on the chemical composition.

\begin{tabular}{|c|c|c|c|c|c|c|c|c|c|c|c|c|c|c|c|c|}
\hline \multirow[t]{2}{*}{$\begin{array}{c}\text { Factor/ } \\
\text { property }\end{array}$} & \multicolumn{2}{|c|}{$\begin{array}{c}\text { Moisture } \\
\text { content } \\
\left(\mathrm{g} .100 \mathrm{~g}^{-1}\right)\end{array}$} & \multicolumn{2}{|c|}{$\begin{array}{l}\text { Protein content } \\
\quad\left(\mathrm{g} .100 \mathrm{~g}^{-1}\right)\end{array}$} & \multicolumn{2}{|c|}{$\begin{array}{c}\text { Ether extract } \\
\left(\mathrm{g} .100 \mathrm{~g} \mathrm{~g}^{-1}\right)\end{array}$} & \multicolumn{2}{|c|}{$\begin{array}{l}\text { Ash content } \\
\left(\mathrm{g} .100 \mathrm{~g}^{-1}\right)\end{array}$} & \multicolumn{2}{|c|}{$\begin{array}{c}\text { Total } \\
\text { carotenoids } \\
\left(\mathrm{mg} .100 \mathrm{~g}^{-1}\right)\end{array}$} & \multicolumn{2}{|c|}{$\begin{array}{c}\text { Calcium } \\
\left(\mathrm{mg} .100 \mathrm{~g}^{-1}\right)\end{array}$} & \multicolumn{2}{|c|}{ 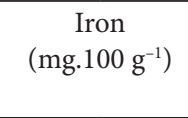 } & \multicolumn{2}{|c|}{  } \\
\hline & Value & $\mathrm{p}$ & Value & $\mathrm{p}$ & Value & $p$ & Value & $p$ & Value & $p$ & Value & $p$ & Value & $\mathrm{p}$ & Value & $\mathrm{p}$ \\
\hline $\mathrm{X}_{1}$ & 0.37 & 0.19 & -0.16 & 0.14 & 0.09 & 0.16 & 0.04 & 0.14 & -0.02 & 0.69 & -0.07 & 0.95 & 0.06 & 0.19 & -0.3 & 0.06 \\
\hline$X_{2}$ & -0.09 & 0.66 & -0.04 & 0.64 & 0.06 & 0.27 & $-0,01$ & 0.77 & 0.04 & 0.39 & -0.38 & 0.69 & -0.03 & 0.47 & -0.15 & 0.14 \\
\hline
\end{tabular}

$\mathrm{X}_{1}$ : temperature; $\mathrm{X}_{2}$ : time. $\mathrm{p}$ : probability at $95 \%$ significance level. ${ }^{*}$ significant at $\mathrm{p}<0.05$.

Table 5. Estimate of the effects on the color parameters.

\begin{tabular}{clccccc}
\hline Factor/ & \multicolumn{2}{c}{$\mathrm{L}$} & \multicolumn{2}{c}{$\mathrm{A}^{*}$} & \multicolumn{2}{c}{$\mathrm{b}^{*}$} \\
\cline { 2 - 7 } parameter & Value & $\mathrm{p}$ & Value & $\mathrm{p}$ & Value & $\mathrm{p}$ \\
\hline Mean & 39.95 & 0.00 & 2.13 & 0.00 & 22.15 & 0.00 \\
$\mathrm{X}_{1}$ & $-0.77^{*}$ & 0.03 & -0.03 & 0.53 & -0.15 & 0.38 \\
$\mathrm{X}_{2}$ & -0.12 & 0.51 & $0.50^{*}$ & 0.01 & -0.23 & 0.22 \\
$\mathrm{X}_{1} \cdot \mathrm{X}_{2}$ & -0.11 & 0.54 & $0.33^{*}$ & 0.01 & -0.22 & 0.22 \\
\hline
\end{tabular}

$\mathrm{X}_{1}$ : temperature; $\mathrm{X}_{2}$ : time. p: probability at $95 \%$ significance level. ${ }^{*}$ significant at $\mathrm{p}<0.05$.

an accentuated degradation of carotenoids with increases in the time/temperature binomial (VASQUEZ-CAICEDO et al., 2007) caused by isomerization of the trans $\beta$-carotene to cis isomers.

\subsection{Variations in the color parameters}

Table 5 show the estimate of the effects on the color parameters.

It can be seen that the factor temperature significantly affected the parameter $L^{*}$. The parameter $a^{*}$ was affected significantly by the time and by the time versus temperature interaction. On the other hand, parameter $b^{*}$ suffered no significant alteration as a function of the factors evaluated. In general the values for $\mathrm{L}^{*}$ tended to decrease with an increase in the process temperature presenting a slight darkening of the processed pulps when compared with the blanched pulp (Table 2). The parameter $\mathrm{a}^{*}$ showed a tendency for the green color to decrease in intensity, mainly under the most extreme time and temperature conditions (process 7 ), which can be explained by the oxidation of the pigments, especially chlorophyll and the carotenoids present in the umbu pulps (XAVIER, 1999) caused by exposition to high temperatures and the high acidity of the pulp. Parameter $b^{*}$, on the other hand, showed a slight decrease in intensity of yellow color also obtaining the lowest value under the most extreme conditions, when compared to the blanched pulp (Table 2). Similar results were found by Jorge et al. (2004) in their study on the pasteurization of umbu pulps in the green stage of maturation and by Ibarz, Pagán and Garza (1999) in their studies on the pasteurization of pear puree. The color parameters of a mixed carrot and orange juice were not affected by HTST pasteurization (RIVAS et al., 2006).

These changes in the color parameters as a function of time and temperature have been extensively studied for various products (CHUTINTRASRI; NOOMHORM, 2007;
GARZA et al., 1999; AHMED; SHIVHARE; SINGH, 2004; KRAPFENBAUER et al., 2006) and according to Lozano and Ibars (1997), who studied different fruit purees, these changes are due to various mechanisms including the Maillard reaction, degradation of pigments, and the polymerization of phenolic compounds; some fruits being are more sensitive than others.

\subsection{Microbiological analysis}

The results obtained in the microbiological analyses of the blanched and processed umbu pulps indicated that the products were obtained within the standards of hygiene recommended by the legislation (yeasts \& molds $<10 \mathrm{CFU} . \mathrm{g}^{-1}$; total coliforms $<0.3 \mathrm{MPN} . \mathrm{g}^{-1}$; standard plate count $<10 \mathrm{CFU} . \mathrm{g}^{-1}$; and the absence of salmonella in $25 \mathrm{~g}$ ) (BRASIL, 2001).

\subsection{Sensory evaluation}

The results in Table 6 show that there were no significant difference between the umbu pulps for any of the aroma and flavor attributes except for bitter taste, to which there was a significant difference $(p<0.05)$ between the reference umbu pulp (blanched pulp) and the pulp processed using the binomial of $96^{\circ} \mathrm{C}$ for 30 seconds. It can be seen that the processed pulp was slightly bitterer than the reference pulp. A slight tendency for an intensification of the green aroma and a loss of the characteristic aroma and flavor could also be seen in the pulp processed at $96{ }^{\circ} \mathrm{C}$ for 30 seconds. On the other hand, the pulp processed at $88{ }^{\circ} \mathrm{C} / 10$ seconds was the most similar to the reference pulp for the majority of the attributes although not showing significant differences from the remaining pulps $(\mathrm{p}>0.05)$.

In a study carried out by Sandi et al. (2003) on correlations between the physicochemical and sensory characteristics of passion fruit juice submitted to pasteurization, significant correlations could be seen between the reducing sugars and bitter taste demonstrating that as inversion of the sucrose progressed, thus increasing the reducing sugar content, the sensory quality decreased. They also observed that the decrease in the characteristic aroma detected in the sensory analyses was accompanied by a decrease in the concentrations of the volatile compounds, which was expected, since various complex reactions occur with time, including oxidation, causing degradation of the volatile compounds and a consequent decrease in their concentrations. Finally, they concluded that pasteurization at $85{ }^{\circ} \mathrm{C} / 27$ seconds resulted in the minor 
Oliveira et al.

Table 6. Mean ranked values given to the sensory attributes of the diluted blanched and heat processed umbu pulps.

\begin{tabular}{|c|c|c|c|c|c|c|c|c|}
\hline \multirow[t]{2}{*}{ Umbu pulp ${ }^{1}$} & \multicolumn{4}{|c|}{ Aroma } & \multicolumn{4}{|c|}{ Flavor } \\
\hline & Characteristic & Acid & Green & Refreshing & Characteristic & Acid taste & green & Bitter taste \\
\hline Blanched & 4.8 & 5.1 & 5.0 & 4.8 & 4.7 & 5.1 & 5.0 & $5.1^{\mathrm{a}}$ \\
\hline 2 & 4.7 & 4.9 & 4.8 & 4.8 & 4.6 & 5.1 & 4.9 & $5.3^{\mathrm{a}}$ \\
\hline 3 & 5.0 & 5.1 & 5.0 & 4.7 & 4.8 & 5.1 & 4.9 & $5.3^{\mathrm{a}}$ \\
\hline 4 & 4.7 & 5.0 & 5.0 & 4.8 & 4.8 & 5.3 & 5.0 & $5.5^{\mathrm{a}}$ \\
\hline $\mathrm{F}_{\text {sample }}$ & $2.46^{\mathrm{ns}}$ & $0.86^{\mathrm{ns}}$ & $1.92^{\mathrm{ns}}$ & $0.55^{\mathrm{ns}}$ & $1.30^{\mathrm{ns}}$ & $0.86^{\mathrm{ns}}$ & $0.16^{\mathrm{ns}}$ & $2.38^{*}$ \\
\hline
\end{tabular}

${ }^{1} 1: 88^{\circ} \mathrm{C} / 10$ seconds; $2: 88^{\circ} \mathrm{C} / 30$ seconds; $3: 92{ }^{\circ} \mathrm{C} / 20$ seconds; $4: 96^{\circ} \mathrm{C} / 10$ seconds; $5: 96{ }^{\circ} \mathrm{C} / 30$ seconds. ns: Non significant. ${ }^{*}$ significant at $\mathrm{p}<0.05$.

alterations in the characteristics studied, whereas treatment at $75^{\circ} \mathrm{C} / 60$ seconds was the most damaging. The profile of volatile compounds in apple juice was not affected by the HTST process (RYE; MERCER, 2003).

\section{Conclusion}

The heat treatments applied resulted in final products without significant alterations on the physicochemical, chemical, and microbiological characteristics. With respect to the color, the parameters of $\mathrm{L}$ and $\mathrm{a}^{*}$ were altered by an increase in temperature indicating a darkening of the pulp. The sensory evaluation indicated that the treatment of $88^{\circ} \mathrm{C} / 10$ seconds was the best processing condition due to the greater similarity to the reference sample (blanched pulp).

\section{References}

AGUILAR-ROSAS, S. F. et al. Thermal and pulsed electric fields pasteurization of apple juice: effects on physicochemical properties and flavour compounds. Journal of Food Engineering, v. 83, p. 41-46, 2007. http://dx.doi.org/10.1016/j.jfoodeng.2006.12.011

AHMED, J.; SHIVHARE, U. S.; SINGH, P. Color Kinetics and rheology of coriander leaf puree and storage characteristics of paste. Food Chemistry, v. 84, p. 605-611, 2004. http://dx.doi.org/10.1016/ S0308-8146(03)00285-1

AMAYA, D. B. A guide to carotenoid analysis in foods. Washington: Ilsi, 2001.

AMERICAN ASSOCIATION OF CEREAL CHEMISTS - AACC. Approved methods of the American Association Of Cereal Chemists. Saint Paul: American Association Of Cereal Chemists, 1995.

ASSOCIATION OF OFFICIAL ANALYTICAL CHEMISTS - AOAC. Official Methods of Analysis of the Association of Official Analytical Chemists. Washington: Association o the f Official Analytical Chemists, 2000.

BISPO, E. S. Estudos dos produtos industrializáveis do umbu (Spondias tuberosa Arr. Câmara). Fortaleza: Universidade Federal do Ceará, 1989.

BRASIL. Agência Nacional de Vigilância Sanitária. Resolução no 12 , de 2 de janeiro de 2001. Regulamento Técnico sobre Padrões Microbiológicos para alimentos. Diário Oficial da República Federativa do Brasil, Brasília, DF, 10 jan. 2001.

BUENO, S. M. et al. Avaliação da qualidade de polpas congeladas. Revista Instituto Adolfo Lutz, v. 61, p. 121-126, 2002.
CHUTINTRASRI, B.; NOOMHORM, A. Color degradation kinetics of pineapple during thermal processing. Lebensmittel-Wissenschaft und Technologie, v. 40, p. 300-306, 2007.

GARZA, S. et al. Non enzymatic browning in peach puree during heating. Food Research International, v. 32, p. 335-343, 1999. http://dx.doi.org/10.1016/S0963-9969(99)00094-0

IBARZ, A.; PAGÁN, J.; GARZA, S. Kinetic models for colour changes in pear puree during heating at relatively high temperatures. Journal of Food Engineering, v. 39, p. 415-422, 1999. http://dx.doi. org/10.1016/S0260-8774(99)00032-1

JORGE, E. C. et al. Caracterización física, físico química y microbiológica de pulpas de "umbu" (Spondias tuberosa Arr. Camâra) obtenidas por metodos combinados. Alimentaria, n. 355, p. 51-55, 2004.

KRAPFENBAUER, G. et al. Effect of thermal treatment on the quality of cloudy apple juice. Journal of Agriculture and Food Chemistry, v. 54, p. 5453-5460, 2006. PMid:16848531. http://dx.doi. org/10.1021/jf0606858

LOZANO, J. E.; IBARZ, A. Colour changes in concentrated fruit pulp during heating at high temperatures. Journal of Food Engineering, v. 31, p. 365-373, 1997. http://dx.doi.org/10.1016/ S0260-8774(96)00079-9

NARAIN, N. et al. Variation in physical and chemical composition during maturation of umbu (Spondias tuberosa) fruits. Food Chemistry, v. 44, p. 255-259, 1992. http://dx.doi.org/10.1016/03088146(92)90047-6

POLICARPO, V. M. et al. Aprovechamiento de la pulpa de "umbu" (Spondias tuberosa Arr. Cam.) verde como alternativa para la producción de dulces em masa. Alimentaria, n. 344, p. 75-77, 2003.

RIVAS, A. et al. Effect of PEF and heat pasteurization on the physical-chemical characteristics of blended orange and carrot juice. Lebensmittel Wissenschaft und Technologie, v. 39, p. $1163-1170,2006$.

RODRIGUES, M. I.; IEMMA, A. F. Planejamento de Experimentos e Otimização de Processos. Campinas: Casa do Pão Editora, 2005.

RYE, G. G.; MERCER, D. G. Changes in headspace volatiles attributes of apple cider resultina from thermal processing and storage. Food Research International, v. 36, p. 167-174, 2003. http://dx.doi. org/10.1016/S0963-9969(02)00133-3

SANDI, D. et al. Correlações entre características físico-químicas e sensoriais em suco de maracujá-amarelo (Passiflora edulis var. flavicarpa) durante armazenamento. Ciência e Tecnologia de 
Alimentos, v. 23, p. 355-361, 2003. http://dx.doi.org/10.1590/ S0101-20612003000300010

SOUSA, M. A. C. et al. Suco de açaí (Euterpe oleracea Mart.): avaliação microbiológica, tratamento térmico e vida de prateleira. Acta Amazônica, v. 36, p. 483-496, 2006.

SPEACK, M. L. Compendium of methods for the microbiological examinations of foods. Washington: American Public Heath Association, 1976.

STONE, H.; SIDEL, J. Sensory evaluation practices. Academic Press: New York, 2004.

UMME, A. et al. Characteristics of soursop natural puree and determination of optimum conditions for pasteurization. Food
Chemistry, v. 58, p. 119-124, 1997. http://dx.doi.org/10.1016/ S0308-8146(96)00226-9

VALDERRAMA, P., MARANGONI, F.; CLEMENTE, E. Efeito do Tratamento Térmico sobre a atividade de peroxidase (POD) e polifenoloxidase (PPO) em Maçã (Mallus comunis). Ciência e Tecnologia de Alimentos, v. 21, p. 321-325, 2001.

VAZQUEZ-CAICEDO, A. L. et al. Effects of thermal processing on $\beta$-carotee stability and enzyme inactivation during transformation of mangoes into purée and nectar. Food Chemistry, v. 102, p. 1172-1186, 2007.

XAVIER, A. D. Caracaterização química e vida de prateleira do doce em massa de umbu (Spondias Tuberosa Arr. Cam.). Belo Horizonte: Universidade Federal de Minas Gerais, 1999. 